\title{
Teachers' experiences about first aid at school
}

\author{
Vivências de professores acerca dos primeiros socorros na escola \\ Vivencias de profesores acerca de los primeros auxilios en la escuela
}

\begin{abstract}
Nelson Miguel Galindo Neto', Gerdane Celene Nunes Carvalho", Régia Christina Moura Barbosa Castro"', Joselany Áfio Caetano"II, Ellen Cristina Barbosa dos Santos ${ }^{\mathrm{IV}}$, Telma Marques da Silva ${ }^{\mathrm{v}}$, Eliane Maria Ribeiro de Vasconcelos ${ }^{\mathrm{V}}$

' Instituto Federal de Educação, Ciência e Tecnologia de Pernambuco, Campus Pesqueira. Pesqueira, Pernambuco, Brazil.

"Universidade Estadual do Piauí. Picos-Piauí, Brazil.

"' Universidade Federal do Ceará. Fortaleza, Ceará, Brazil.

"v Universidade Federal de Pernambuco. Vitória de Santo Antão, Pernambuco, Brazil.

${ }^{v}$ Universidade de Federal de Pernambuco. Recife, Pernambuco, Brazil.
\end{abstract}

\begin{abstract}
How to cite this article:
Galindo Neto NM, Carvalho GCN, Castro RCMB, Caetano JA, Santos ECB, Silva TM, et al. Teachers' experiences about first aid at school. Rev Bras Enferm [Internet]. 2018;71(Suppl 4):1678-84. [Thematic Issue: Education and teaching in Nursing] DOI: http://dx.doi.org/10.1590/0034-7167-2017-0715
\end{abstract}

Submission: 10-11-2017 Approval: 03-10-2018

\begin{abstract}
Objective: To unveil the experiences of primary and elementary school teachers about first aid at school. Method: a descriptive, qualitative study, conducted in May 2014, from a focus group with nine teachers from the municipal network of Bom Jesus-PI. Audio recording occurred, content was transcribed, and data were processed by IRAMUTEQ software and analyzed from the Descendant Hierarchical Classification. Results: Three classes were obtained: Teachers' knowledge about first aid (influence of maternal experience, belief in popular myths and awareness of lack of preparation were indicated); Feelings in situations of urgency and emergency (anguish, fear and concern); First aid at school, (occurring in class or during break time, coming from collisions and syncope). Final considerations: The research evidenced experiences based on popular beliefs, family experiences and knowledge gaps. The lack of preparation was evidenced by the teachers' reports about having misconduct during first aid at school.
\end{abstract}

Descriptors: First Aid; Emergencies; School Health; Health Promotion; Qualitative Research.

\section{RESUMO}

Objetivo: desvelar as vivências de professores do ensino infantil e fundamental sobre primeiros socorros na escola. Método: estudo descritivo, qualitativo realizado em maio de 2014, a partir de grupo focal com nove professores da rede municipal de Bom Jesus-PI. Ocorreu gravação de áudio, o conteúdo foi transcrito, os dados foram processados no software IRAMUTEQ e analisados a partir da Classificação Hierárquica Descendente. Resultados: foram obtidas três classes: "Conhecimento dos professores acerca dos primeiros socorros" (apontou influência da experiência materna, crença em mitos populares e consciência do despreparo); "Sentimentos em situações de urgência e emergência" (angústia, medo e preocupação); e "Primeiros socorros vivenciados na escola", (ocorridos em sala de aula ou durante recreação, oriundos de pancadas e síncope). Considerações finais: A pesquisa evidenciou vivências baseadas em crenças populares, experiências familiares e lacuna de conhecimentos. O despreparo foi evidenciado pelo relato dos professores acerca de terem realizado condutas inadequadas durante primeiros socorros na escola.

Descritores: Primeiros Socorros; Emergências; Saúde Escolar; Promoção da Saúde; Pesquisa Qualitativa.

\section{RESUMEN}

Objetivo: desvelar las vivencias de profesores de la enseñanza infantil y fundamental sobre primeros auxilios en la escuela. Método: estudio descriptivo, cualitativo realizado en mayo de 2014, a partir de un grupo focal con nueve profesores de la red municipal de Bom Jesús-PI. La grabación de audio, el contenido fue transcrito, los datos fueron procesados en el software IRAMUTEQ y analizados a partir de la Clasificación jerárquica descendente. Resultados: se obtuvieron tres clases: "Conocimiento de los profesores acerca de los primeros auxilios" (apuntó influencia de la experiencia materna, creencia en mitos populares y conciencia del despreparo); "Sentimientos en situaciones de urgencia y emergencia" (angustia, miedo y preocupación); y "Primeros auxilios vivenciados en la escuela", (ocurridos en el aula o durante la recreación, procedentes de golpes y síncope). Consideraciones finales: La investigación 
evidenció vivencias basadas en creencias populares, experiencias familiares y laguna de conocimientos. El despreparo fue evidenciado por el relato de los profesores acerca de haber realizado conductas inadecuadas durante primeros auxilios en la escuela.

Descriptores: Primeros Auxilios; Emergencias; Salud Escolar; Promoción de la Salud; Investigación Cualitativa.

\section{INTRODUCTION}

The school is an environment, in which various activities are developed, among them, teaching, break time, play and socialization, becoming a suitable place for accidents to happen ${ }^{(1)}$.

A study conducted in the Brazilian capitals showed that the age bracket of the school age ( 0 to 19 years) corresponded to $45.7 \%$ of the visits due to external causes in emergency services ${ }^{(2)}$, while another Brazilian study also indicates that, in the pediatric emergence, there was a statistical association between falls and the school environment ${ }^{(3)}$

First aid is defined as the action performed on some victim, in the face of an emergency situation ${ }^{(4)}$. As the arrival of health professionals can usually take some time, these actions need to be initiated by people present at the place who witness the situation ${ }^{(5)}$. Thus, it is necessary that the population, in its diversity of contexts, be empowered and takes the leading role of first aid actions ${ }^{(6)}$.

Empowerment, in an integral perspective, refers to the active participation of individuals in decision-making processes, in strengthening collective modes of planning and decision-making in health actions ${ }^{(7)}$. One strategy that contributes to empowerment in the school environment is the School Health Program (SHP). Since 2007, this program has included the intersectoriality between health and education, based on the Family Health Strategy with students and teachers in the school environment, in diagnostic and prevention activities ${ }^{(8)}$. In this context, the theme "first aid" in the school corroborates with the activities that can be carried out in the SHP, because it deals with a subject related to health that is often experienced in school routine ${ }^{(9)}$.

Teachers are potential witnesses who need to carry out first aid in cases of accidents at school, however, although they participate in courses on the subject, these professionals adopt incorrect conduct in the event of accidents ${ }^{(10)}$. In this setting, it is incumbent upon health professionals, especially nurses, to implement measures that contribute to the autonomy and empowerment of teachers, on the issues surrounding the issue, so that effective training of these professionals can occur ${ }^{(11)}$.

For educational interventions to have a greater chance of success, it is important that they are planned based on the understanding of the objective and subjective factors that permeate the situation to be addressed. Thus, revealing the experience of teachers on first aid gains relevance, when considering that health education strategies can be planned and performed by nurses, with a view to community empowerment, from an understanding of past experiences and particularities arising from them.

\section{OBJECTIVE}

To unveil experiences of primary and elementary school teachers about first aid in school in the light of the theoretical framework of empowerment.

\section{METHOD}

\section{Ethical aspects}

The performance of this study occurred as established by Resolution 466/12 on research involving human subjects and was approved by the Research Ethics Committee Involving Human Beings of the Health Sciences Center of the Universidade Federal de Pernambuco.

\section{Type of study}

To reach the proposed objective, a descriptive, exploratory study with a qualitative approach was carried out.

\section{Study setting}

The study setting consisted of the 14 municipal public schools located in the municipality of Bom Jesus, in the State of Piauí.

\section{Data source}

The focus group was used as a data source and should be formed with the participation of six to ten people ${ }^{(12)}$. When considering the possibility of losses, 30 teachers, selected by simple random sampling were invited from the list of teachers of the Municipal Secretary of Education of said municipality. Of these, nine agreed to participate in the study and therefore integrated the sample.

The selection was based on the following inclusion criteria: being a teacher of kindergarten or elementary education, since the students of these age groups present risk factors, inherent to their development stage, that contributes to the occurrence of accidents; and have more than one year as a teacher, which increases the chance of experiencing some emergency situation with the students.

Exclusion criteria were adopted: removal of any type during the period in which the data were collected and other professional activity to be performed prior to the first aid, such as a firefighter or first aid driver, which could lead to bias in the results.

The profile of the teachers who participated in the present study was obtained by completing a form that addressed socioeconomic and professional information.

\section{Collection and data organization}

For data collection a script was used with the following guiding questions to be contemplated by the group: Tell me about situations that you experienced in which some students had to be rescued. How was it for you to come across these situations?

Data collection took place in May 2014. The focus group was held in a room intended for meetings of the Municipal Department of Education. Two meetings were held with the same group of nine teachers, the first one lasted 50 minutes and the second lasted 49 minutes, with an interval of two days between both, given the readiness of the teachers to meet again. It is noteworthy that two meetings were necessary because the focus group's goal 
could not be reached only in the first one, given the volume of speeches generated from the large number of first aid situations experienced by teachers. In addition, it was in the second meeting that the saturation of the content was obtained.

The operation of the focus group occurred due to the moderation of the researcher in the discussion of the group and the technical conduction was given by the performance of a previously trained observer. The teachers were accommodated in a circle and two MP3 players were positioned in the center of this for audio recording. The full transcription of the content that was recorded after each meeting.

\section{Data analysis}

The data were processed with the software IRAMUTEQ (Interface of Multi-Dimensional Analysis of Textes et de Questionnaires) version 0.7 alpha 2 , which works by anchoring the program $\mathrm{R}$. The program, according to the size of the text, divides the written contents in segments, generally of three lines, called "segments" and allows the analysis with simple methods, such as obtaining the frequency of words (basic lexicography), to more complex forms, such as multivariate analysis ${ }^{(13)}$. At the present, a multivariate analysis was performed using the Descendant Hierarchical Classification (DHC) method. This method consists of grouping into classes of the textual segments, from the frequency and chi-square of the vocabulary ${ }^{(13)}$. In such grouping, the segments of a given class have similar vocabulary with each other and, concurrently, vocabulary different from the segments of the other classes, so that DHC is presented by the software in the form of a dendrogram and shows the relation between the classes obtained in textual analysis ${ }^{(13)}$.

The text corpus resulting from the transcription was compatible and feasible to be analyzed by IRAMUTEQ, since it had 1228 words and 202 textual segments, with use of $80.2 \%$ of the segments for processing by the program and the grouping of these resulted in three classes: "Knowledge about first aid"; "Feelings in situations of urgency and emergency"; and "First aid at school".

\section{RESULTS}

All study participants were women and in relation to age, the age range between 30 and 40 years prevailed. As for marital status, the majority were married (five female teachers) and had children (eight female teachers).

In the professional profile, it was observed that the majority had more than eight years of teaching experience (eight teachers) and the predominant working regime in the group was 40 hours a week, fulfilled in the morning and afternoon shifts. The complementary training focused on pedagogical training courses, experienced by three teachers and the predominant qualification was specialist, in six participants, the others had the highest graduation degree.

IRAMUTEQ divided the text into 202 segments and the grouping of these resulted in the obtaining of three classes, detailed in Figure 1.

In class 1 (teachers' knowledge about first aid) it is observed that some first aid procedures are known to the teachers and were obtained mainly through maternal experience, because they involve caring for the children, who become ill and mothers to seek information about the correct way to help. Thus, motherhood is presented by the teachers as the motivation for empowerment in first aid.

What we know about first aid is because we are mothers and because we have also helped our children. If it is collision you have to put ice, if bleeding needs to stop the bleeding by tightening the place with a clean cloth. (P7)

Despite this experience, there is a belief based on popular myths, which teachers report having had access through informal conversations, in which they learned of cases where such behaviors (popular myths) were successful in saving or treating an emergency situation.

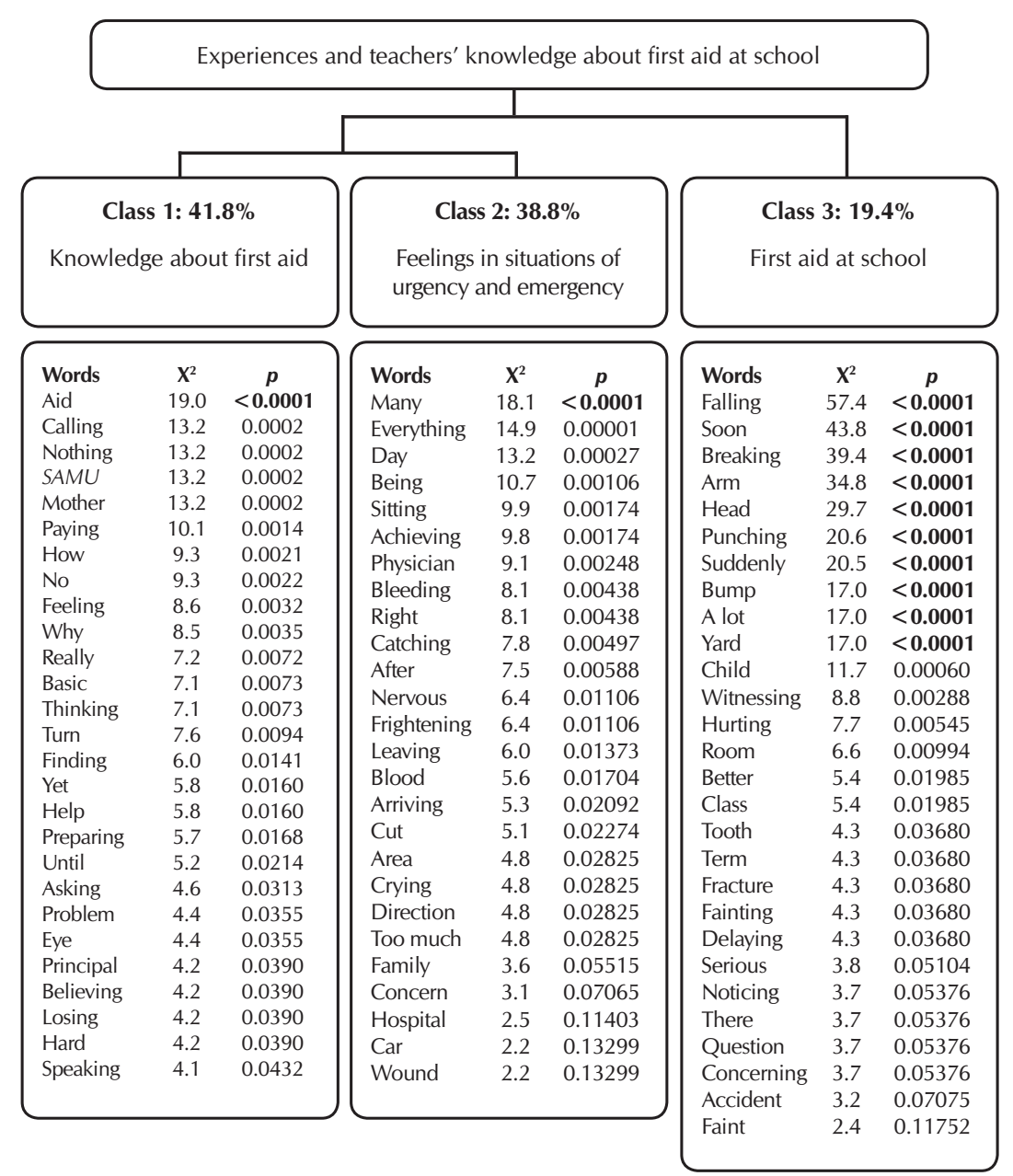

Figure 1 - Dendrogram of words distributed by classes, Fortaleza City, Ceará State, Brazil, 2017 
I've heard that when the snake bites you have to tie up the place so the blood doesn't flow, and then you have to drill and squeeze the spot to get the blood around it. (P1)

The speeches show that there is a lack of preparation among the teachers to provide first aid, especially in the face of the complexity that may involve a case of urgency and emergency. The argument presented for such lack of preparation is about the academic training being directed to teaching, without any training on first aid and points to the need for the teacher's empowerment for first aid at school to be contemplated since the training.

When it happens we don't know what to do, we are teachers, we are not prepared for it, we didn't have this training in our course. (P3)

Teachers, despite believing that they do not have the necessary training, demonstrate the importance of calling the pre-hospital mobile service so that the victim can receive appropriate care. However, the activation of health professionals is pointed out as the only solution to the situation.

And some time ago it was more difficult, because we didn't have SAMU in the city yet. Now it's less complicated, because in case of an emergency we can call the SAMU, the only solution is to call the SAMU. (P2)

Class 2 (feelings in situations of urgency and emergency) presents expressed feelings, intensified by the lack of empowerment to perform first aid, of which anguish, concern and fear can be highlighted, due to the fact that teachers do not know how to act while health professionals arrive at the place) and by exposure to atypical situations of their routine, from sensorial stimuli that refer to the risk of death, such as the visualization of blood.

Even though you have sent SAMU come to pick you up, you get anguished all the time. Because you didn't know how to perform first aid, you become desperate and don't know how to do it. (P6)

As we have no experience in how to help the injured person, you feel despaired, everyone gets frightened seeing blood. (P8)

The feelings reported by teachers are generated not only from the urgency and seriousness of the situation of the student who needs help, but from the family context involved, in which the teacher may suffer aggression from the family and be accused of neglecting the students' safety, which was under their responsibility.

We are worried that the child will get hurt, because often parents may not understand it and they think it is the teacher's lack of care. (P5)

In the first place you think about the family, what it will say. Often the family doesn't understand, parents are not always comprehensible, when they arrive fight has already begun. (P7)

According to the third class (first aid at school), the injuries that teachers have witnessed in school occurred in the classroom or during recreational activity, affected limbs, head and teeth and came from falls and collisions, which caused fractures, syncope and edema, so that the need to empower teachers to act in such situations is pointed out.

There in the place where I work, at the time of physical education, the student came running and banged his head well on the corner of the wall, at the time the bump came out. (P9)

In our school what happens a lot is the issue of cuts, they have deep wounds on the forehead, the arm, when they fall. (P4)

He was playing at the time of physical education and he suddenly fell. (P1)

A child in the yard, playing with his/her classmates, fell and broke his/her arm. (P3)

\section{DISCUSSION}

The current model for health promotion, reorganized and operationalized by the Family Health Strategy, has as one of the scope of action the School Health Program (SHP). This program addresses the relevant joint action of health and education to promote health in the school environment, based on five components, which focus on the monitoring/evaluation of school health and prevention activities ${ }^{(8)}$. Despite the relevant contribution of the SHP, the need to contemplate first aid in the school, with the qualification of the teachers in the thematic one, stands out.

In addition, the findings of the present study demonstrated a paradox between theory and practice, in which teachers had incipient knowledge and skills for first aid and, above all, showed fear and insecurity to communicate the fact to family members, which makes it imperative health, education and family, making this aspect of the recommendations of the School Health Program.

It was possible to observe the lacuna that reflects in experiences based on decision making subsidized by lack of preparation. A quantitative Brazilian study pointed out the lack of knowledge about first aid among teachers ${ }^{(14)}$, as well as studies from Nigeria and China showed a similar reality with teachers about cardiopulmonary resuscitation ${ }^{(15-16)}$. This reality is not only specific to the school environment, it is rare for people who have knowledge of first aid also in the work environment, which represents a negative aspect in health management processes, which are characterized by the lack of immediate care or by performing inappropriate practices ${ }^{(17)}$.

These results are not in line with the demands of the current paradigm aimed at promoting health with a focus on the citizen, in which the subject becomes the protagonist of his life and health process through empowerment ${ }^{(18)}$. Knowledge in first aid is indispensable for different social and professional segments, considering the occurrence of emergency situations in the most varied groups of the population ${ }^{(19)}$, especially in the school, which has a high flow of students without necessarily having a professional qualified to perform first aid correctly.

Referring to the knowledge coming from the maternal sense, it is emphasized that previous experience, if successful, is a source of knowledge about first aid for the teachers. In addition, prior knowledge can be taken as the basis for building new knowledge in the perspective of expanding learning and re-meaning concepts ${ }^{(20)}$. Therefore, teachers' family experiences 
should be considered in the process of building knowledge about first aid at school, since they can guide specific decisions of health teachers and can make a difference in the planning and effectiveness of educational interventions.

It was relevant the unveiling on the prioritization of teachers to call the SAMU (ambulance service) quickly. Such prioritization is important, since the early activation of the mobile emergency service is associated with increased survival ${ }^{(21)}$. Despite this, it is contemplated the teachers' need to understand that they can institute decisive ways to save, even while health professionals are not yet present.

Teachers of kindergarten and elementary education have demonstrated a lack of knowledge about their own lack of preparation to act in emergency situations at school. Studies in Brazil, India, and Africa have shown similar results for teachers facing accidents at school, acknowledging that they have limited knowledge to act correctly and feel insecure ${ }^{(1,22-24)}$. The empowerment gap for first aid interventions requires an analysis of their roots. Although teachers coexisted with the imminent possibility of accidents, there is often no preparation to make them fit to practice this practice. Lack of knowledge may be associated with the absence of inadequate training or training ${ }^{(25)}$. And the lack of training, reflected in lack of preparation, contributes to the fact that the experiences are not constructive, traumatic and permeated by negative feelings.

Regarding the feelings reported by the teachers, they corroborate qualitative research from Norway, which interviewed people who provided first aid for victims of cardiovascular collapse and whose results show the presence of nervousness, fear and anguish ${ }^{(26)}$. Such feelings are commonplace in the face of the complexity of the situation and can be minimized if teachers feel more secure in being trained.

The injuries experienced and reported in the focal group are common in the school environment, since the activities carried out in schools, especially recreational ones, provide the occurrence of emergencies, such as falls, with consequent fracture, trauma, cuts and wounds, as well as emergencies such as syncope and edemas $^{(1,27-28)}$. In this context, it is necessary to multiply the information regarding the correct conducts, such as the indication of keeping any member who is under suspicion of being fractured; application of ice to collision places and, in cases of nasal bleeding, the application of ice may be performed on the forehead and neck; use of a clean compress for direct pressure in cases of bleeding, with due care to wrap hands in impermeable material (such as a plastic bag), in order to avoid contact with biological material(4).

When considering the relevance of the teachers to know the first aid for the abovementioned diseases, it is important to highlight the need to include such professionals in the planning and implementation of health education, so that there is greater motivation and involvement and the probability of the contents addressed corresponds to the demands they experienced at school ${ }^{(18)}$. Thus, the contribution of the actors involved will be so that teachers are not only spectators, but active subjects of the teaching-learning process.

In this context, training on the subject is presented as a coping strategy to contribute to its safety and to make teachers empowered. It is pertinent to emphasize that the first aid empowerment in the school context must transpose the transmission of information about the correct first aid procedures and must include the identification of the risks of accidents, which pervade its kinematics, the determinants based on traditional conceptions of common sense, as well as contemporary issues such as those related to family structure, parental social roles and power relations, which are factors that affect children's education and risk behavior.

The quality of educational interventions that contribute to this process of empowerment and active involvement need to be carried out by professionals who have first aid training, who work in Primary Health Care and are teachers.

In view of the educating role of the nursing professional, the professional must integrate the family health team that works in the school and consider that the structure and context of the Nursing workplaces demand the perception of specifics and decision making adapted to each reality, that consider social, economic and technological determinants ${ }^{299}$, it is pointed out the privileged strategic position that Nursing occupies to approach the first aid in the school.

The problem in question requires the reflection and attitude of health professionals, especially nurses, about their role in empowering first aid teachers. In this process, Nursing has the function of performing the situational diagnosis of the subjects and the determinants involved in local particularities, planning health education, implementing and evaluating, based on the holistic view and the critical-reflexive reasoning about the situation.

In order to face the knowledge and empowerment gaps observed, the educational practices carried out by nurses converge to the aggregation of popular knowledge and professional practice, making the nurse an agent of transformation in the perspective of subsidizing the autonomy and the protagonism of the subjects in favor of their life and health ${ }^{(30)}$.

\section{Study limitations}

As a limitation of the present study, it is important to highlight the research setting, since it was carried out with primary and elementary school teachers in public schools, so that the findings obtained may not reflect the experiences of professionals who teach at other levels of education (pre-school or high school) or working in private educational institutions.

\section{Contributions to Nursing, Health or Public Policy}

To unveil the experiences of primary and elementary school teachers about first aid, from the identified classes, contributes to the understanding of reality and to the analysis of the theoretical and practical aspects of a problem inherent to the demands of the school context. In addition, as regards Nursing, the study reinforces that the approach of professionals should be based on intersectoriality, directing actions planned according to singularities and empowering teachers as co-responsible in the management process in the emergency situations.

\section{FINAL CONSIDERATIONS}

The research evidenced experiences based on popular beliefs, lack of knowledge and family experiences, where the lack of preparation resulted in the indication of inadequate behaviors or the conduct of waiting for the SAMU, without instituting possible first aid.

Teachers pointed out that there is a lack of empowerment about first aid in training, while presenting motherhood as a potential motivation for such empowerment to be sought. In addition, they 
stressed the need to empower themselves to act on the problems experienced (fractures, syncope and edema from collisions and falls) and that the absence of empowerment culminates in the experience of feelings of anguish, concern and fear.

Faced with the demand for first aid in the school environment, the above problem must awaken in health professionals and training institutions, from an intersectoral perspective, the need to implement permanent education measures for teachers in order to provide theoretical background and empowerment to implement preventive measures and correct first aid procedures.

In addition, it is recommended that the contemporary risk factors present within the family and society be considered in order to encourage the behavior of schoolchildren convergent with the decrease of number of accidents, which contributes to health promotion practice with regard to identification determinants and contribution of the actors involved in the process.

\section{ERRATUM}

Article "Teachers' experiences about first aid at school", with number of DOI: http://dx.doi.org/10.1590/0034-7167-20170715, published in the journal Revista Brasileira de Enfermagem, v71(suppl 4):1678-84, on page 1678:

Where it read:

\section{"Nelson Miguel Galindo Neto', Gerdane Celene Nunes Carvalho", Régia Christina Moura Barbosa Castro"I', Joselany Áfio Caetano"II, Ellen Cristina Barbosa dos Santos ${ }^{\mathrm{IV}}$, Telma Marques da Silvav, Eliane Maria Ribeiro de Vasconcelos ${ }^{\mathrm{V}}$}

' Universidade de São Paulo, School of Nursing of Ribeirão Preto. Ribeirão Preto, São Paulo, Brazil."
Read:

\section{"Nelson Miguel Galindo Neto", Gerdane Celene Nunes Carvalho", Régia Christina Moura Barbosa Castro"II, Joselany Áfio Caetano"II, Ellen Cristina Barbosa dos Santos ${ }^{\mathrm{IV}}$, Telma Marques da Silvav, Eliane Maria Ribeiro de Vasconcelos ${ }^{\mathrm{V}}$}

' Instituto Federal de Educação, Ciência e Tecnologia de Pernambuco, Campus Pesqueira. Pesqueira, Pernambuco, Brazil.

"Universidade Estadual do Piauí. Picos-Piauí, Brazil.

"I' Universidade Federal do Ceará. Fortaleza, Ceará, Brazil.

IV Universidade Federal de Pernambuco.

Vitória de Santo Antão, Pernambuco, Brazil.

${ }^{\vee}$ Universidade de Federal de Pernambuco. Recife, Pernambuco, Brazil."

\section{REFERENCES}

1. Maia MFM, Anjos MRR, Miranda Neto JT, Gomes MCS, Deusdará FF. Primeiros socorros nas aulas de educação física nas escolas municipais de uma cidade no norte do estado de Minas Gerais. Col Pesq Educ Física[Internet]. 2012[cited 2017 Jan 14];11(1):195204. Available from: http://www.conhecer.org.br/enciclop/2015a/situacoes.pdf

2. Singletary EM, Charlton NP, Epstein JL, Ferguson JD, Jensen JL, MacPherson AI, et al. First Aid: 2015 American Heart Association and American Red Cross Guidelines Update for First Aid. Circulation [Internet]. 2015[cited 2018 Jan 20];132(Suppl-2)18:574-89. Available from: http://circ.ahajournals.org/content/132/18_suppl_2/S5744

3. Callaway CW. Cardiac arrest in any location: the need for fewer bystanders and more layperson rescuers. JAMA Cardiol[Internet]. 2017[cited 2017 Jan 14];2(5):514-5. Available from: https://www.ncbi.nlm.nih.gov/pubmed/28297005

4. Oliveira MR, Leonel ARA, Montezeli JH, Gastaldi AB, Martins EAP, Caveião C. Conception of undergraduate nursing students on the practice of health education on first aid. Rev Rene[Internet]. 2015[cited 2017 Jan 14];16(2):150-8. Available from: http://www. revistarene.ufc.br/revista/index.php/revista/article/view/1863

5. Malta DC, Mascarenhas MDM, Bernal RTI, Andrade SSCA, Neves ACM, Melo EM, et al. Causas externas em adolescentes: atendimentos em serviços sentinelas de urgência e emergência nas Capitais Brasileiras-2009. Cienc Saude Colet[Internet]. 2012[cited 2017 Jan 14];17(9):2291-304. Available from: http://www.scielo.br/pdf/csc/v17n9/a11v17n9.pdf

6. Malta DC, Silva MMA, Mascarenhas MDM, Sá NNB, Morais Neto ON, Bernal RTI, et al. The characteristics and factors of emergency service visits for falls. Rev Saúde Publica[Internet]. 2012[cited 2017 Jan 14];46(1):128-37. Available from: http://www.scielo.br/ $\mathrm{pdf} / \mathrm{rsp} / \mathrm{v} 46 \mathrm{n} 1 / \mathrm{en}$ 3200.pdf

7. Silva LGS, Costa JB, Furtado LGS, Tavares JB, Costa JLD. Primeiros socorros e prevenção de acidentes no ambiente escolar: intervenção em unidade de ensino. Enferm Foco[Internet]. 2017[cited 2017 Oct 03];8(3):25-29. Available from: http://revista.portalcofen.gov. br/index.php/enfermagem/article/view/893/394

8. Oliveira IS, Souza IP, Marques SM, Cruz AF. Knowledge of educators on prevention of accidents in childhood. Rev Enferm UFPE[Internet]. 2014 [cited 2017 Jan 03];8(2):279-85. Available from: http://www.revista.ufpe.br/revistaenfermagem/index.php/ revista/article/view/3390/pdf 4532 
9. Berardinelli NAC, Guedes NAC, Ramos JP, Silva MGN. Tecnologia educacional como estratégia de empoderamento de pessoas com enfermidades crônicas. Rev Enferm UERJ[Internet]. 2014[cited 2017 Jan 14];22(5):603-9. Available from: http://www.facenf. uerj.br/v22n5/v22n5a04.pdf

10. Taddeo PS, Gomes KWL, Caprara A, Gomes AMA, Oliveira GC, Moreira TMM. Acesso, prática educativa e empoderamento de pacientes com doenças crônicas. Ciênc Saude Colet[Internet]. 2012[cited 2017 Jan 14];17(11):2923-30. Available from: http:// www.scielo.br/pdf/csc/v17n11/v17n11a08.pdf

11. Lopes FTP, Cordeiro MP. Entrevistas individuais e grupos focais: alguns cuidados ético-metodológicos. Rev Espaç Acadêmic[Internet]. 2011[cited 2017 Jan 14];11(123):58-67. Available from:http://www.periodicos.uem.br/ojs/index.php/EspacoAcademico/article/view/12486/7594

12. Camargo BV, Justo AM. Tutorial para o uso do software de análise textual IRAMUTEQ. Laboratório de Psicologia Social da Comunicação e Cognição - LACCOS [Internet]. 2013[cited 2015 Apr 02]; Universidade Federal de Santa Catarina. Available from: http://www.iramuteq.org/documentation/fichiers/tutoriel-en-portugais

13. Brasil. Ministério da Saúde. Caderno do gestor do PSE. Brasília: MS; 2015.

14. Calandrim LF, Santos AB , Oliveira LR, Massaro LG, Vedovato CA, Boaventura AP. First aid at school: teacher and staff training. Rev Rene[Internet]. 2017 [cited 2018 Jan 20];18(3):292-9. Available from: http://www.revistarene.ufc.br/revista/index.php/revista/ article/view/2641

15. Onyeaso AO, Onyeaso OO. Comparison of Practising and Student Teachers' Knowledge of Cardiopulmonary Resuscitation in Nigeria. Public Health Res[Internet]. 2017[cited 2018 Jan 20];7(6):143-7.Available from: http://article.sapub.org/10.5923.j.phr.20170706.03.html

16. Hung MSW, Chow MCM, Chu TTW, Wong PP, Nam WY, Chan VLK, et al. College students' knowledge and attitudes toward bystander cardiopulmonary resuscitation: a cross-sectional survey. Cogent Med[Internet]. 2017[cited 2018 Jan 20];4(1):1334408. Available from: https://www.cogentoa.com/article/10.1080/2331205X.2017.13344088

17. Ragadali Filho A, Perira NA, Leal I, Anjos QS, Loose JTT. A importância do treinamento de primeiros socorros no trabalho. Rev Saberes [Internet]. 2015[cited 2018 Jan 20];2(3):114-25. Available from: http://facsaopaulo.edu.br/media/files/35/35_1390.pdf

18. Pinto BK, Soares DC, Cecagno D, Muniz RM. Promoção da saúde e intersetorialidade: um processo em construção. Rev Min Enferm[Internet]. 2012 [cited 2017 Jan 14];16(4):487-93. Available from: http://www.reme.org.br/artigo/detalhes/552

19. Costa CWA, Moura DL, Costa FLO, Melo RS, Moreira SR. Unidade didática de ensino dos primeiros socorros para escolares: efeitos do aprendizado. Pensar Prát [Internet]. 2015[cited 2017 Jan 14];18(2):338-49. Available from: https://www.revistas.ufg.br/fef/article/view/30205

20. Chagas JJT, Sovierzoski HH. Um diálogo sobre aprendizagem significativa, conhecimento prévio e ensino de ciências. Meaningful Learn Rev[Internet]. 2014[cited 2017 Jan 14];4(3):37-52. Available from: http://www.if.ufrgs.br/asr/artigos/Artigo_ID67/v4_n3_a2014.pdf

21. Nichol G, Cobb LA, Yin L, Maynard C, Olsufka M, Larsen J, et al. Briefer activation time is associated with better outcomes after out-of-hospital cardiac arrest. Resuscitation[Internet]. 2016[cited 2018 Jan 20];107:139-44. Available from: https://www.ncbi.nlm. nih.gov/pubmed/274524900

22. Oliveira Jr MA, Silva Jr CJ, Toledo EM. O Conhecimento em Pronto-Socorrismo de Professores da Rede Municipal de Ensino do Ciclo I de Cruzeiro-SP. ECCOM [Internet]. 2013[cited 2018 Jan 20];4(7):39-48. Available from: http://publicacoes.fatea.br/index. php/eccom/article/view/591

23. Joseph N, Narayanan T, Zakaria S, Nair AV, Belayutham L, Subramanian AM, et al. Awareness, attitudes and practices of first aid among school teachers in Mangalore, South India. J Prim Health Care[Internet]. 2015[cited 2017 Jan 14];7(4):274-81. Available from: https://www.ncbi.nlm.nih.gov/pubmed/26668832

24. Ngayimbesha A, Hatungimana O. Evaluation of first aid knowledge among elementary school teacher in Burundi. Int J Sport Scienc Fit[Internet]. 2015[cited 2017 Jan 14];5(2):304. Available from: http://www.ijssf.org/PDF/v05issue02abs13.pdf

25. Sönmez Y, Uskun E, Pehlivan A. Knowledge levels of pre-school teachers related with basic first-aid practices, Isparta sample. Turk Pediatr Ars[Internet]. 2014[cited 2017 Jan 14];49(3):238-46. Available from: https://www.ncbi.nlm.nih.gov/pubmed/26078669

26. Mathiesen WT, Bjørshol CA, Braut GS, Søreide E. Reactions and coping strategies in lay rescuers who have provided CPR to outof-hospital cardiac arrest victims: a qualitative study. BMJ Open[Internet]. 2016[cited 2018 Jan 20];6:e010671. Available from: http://bmjopen.bmj.com/content/6/5/e0106711

27. Eze CN, Ebuehi OM, Brigo F, Otte WM, Igwe SC. Effect of health education on trainee teacher's knowledge, attitudes, and first AID management of epilepsy: an interventional study. Seizure[Internet]. 2015[cited 2017 Jan 14];33:46-53. Available from: https:// www.ncbi.nlm.nih.gov/pubmed/26558347

28. Galindo Neto NM, Pereira JCN, Muniz MLC, Mallmann DG, Souza NMG, Neri MFS, et al. Health education intervention on first aid in school: integrative review. Int Arch Med[Internet]. 2016[cited 2017 Jan 14];9(144):1-7.Available from: http://imed.pub/ojs/ index.php/iam/article/view/1733

29. Pivoto FV, Filho WDL, Lunardi Filho WD, Silva PA. Organization of work and the production of subjectivity of the nurse related to the nursing process. Esc Anna Nery Rev Enferm[Internet]. 2017[cited 2017 Jan 14];21(1):e20170014. Available from:http://www. scielo.br/pdf/ean/v21n1/en_1414-8145-ean-21-01-e20170014.pdf

30. Progianti JM, Costa RF. Práticas educativas desenvolvidas por enfermeiras: repercussões sobre vivências de mulheres na gestação e no parto. Rev Bras Enferm[Internet]. 2012[cited 2017 Jan 14];65(2):257-63. Available from: http://www.scielo.br/pdf/reben/ v65n2/v65n2a09.pdf 